\title{
The best educational systems in the world on example of European and Asian countries
}

\begin{abstract}
The article describes 5 countries from the world: South Korea, Japan, Singapore, Hong Kong, Finland that have the best and unusual educational systems. Thanks to the new approach to the teaching, students become very well-educated when graduate. The text emphasises the importance of foreign language knowledge. It is very interesting how much different is the approach to students in Asian countries and in Finland but both systems eventually provide very good education level to their students. The another part of the article bases for characteristic of two other EU countries - Romania and Poland. In these countries, the internal educational systems are quite similar to each other and guarantee their students very good education level. Thanks to the attendance in Erasmus exchange programme, Romanian and Polish students can broaden their mind abroad.
\end{abstract}

Keywords: educational system, Asian countries, Finland, approach to teaching, Erasmus, Poland, Romania, studying, prestige

JEL Classification: 10, 12, PO.

\section{Introduction}

The Asian countries and Finland have been leading in the ranking of the best international education systems for many years. Students in these countries achieve superior results in competency tests, and the work as a teacher is a real 
prestige in these countries. What is the success of the best education systems of the world?

Graduation with being well-educated is treated as something very important. However, in many countries, the well-developed education system is still "the object to do". It is obvious that not all countries have the same emphasis on the education system and the one education system is more efficient than the other.

The Pearson Publishing Group, which is the leader in scientific publications, regularly publishes rankings of successful teaching countries. The research that has been conducted in many countries, is based on the implementation of rigorous methods of measuring the social progress of the examined countries basing on the level of education according to the regulations of the United Nations Organisation.

The latest report of The Pearson Publishing Group The Learning Curve 2014 proved that the top five educational systems in the world are in: South Korea, Japan, Singapore, Hong Kong and Finland ${ }^{1}$.

\section{Five countries of the world with the best modern educational systems}

\section{South Korea}

South Korea is highly investing in the education. The expenditure on education is nearly $7.7 \%$ of the GDP. This is the third best result among the Organisation for Economic Co-operation and Development (OECD) countries after Denmark and Iceland. In comparison, the average expenditure on education in OECD countries is about $6 \%$.

The students in South Korea are constantly under tremendous social pressure - the development and achievements are the most important things here. They do not use the words like "failure" or "lack of ability". Koreans believe that with hard work you can achieve everything. Young people in South Korean go to school all year round. They study in public schools, private ones, after classes and even though in their spare time. According to the research of Ministry of Education, in 2012 Korean parents spent almost 18 billion dollars on tutoring for their children. Four of the five Korean primary school students attend private lessons. The number of fellow pupils in the classes groups of Korean schools are the most numerous in the world. The lower secondary

\footnotetext{
${ }^{1}$ Fallon, J., \& Barber, M., \& the others. (2014). The Learning Curve 2014. [ONLINE], available at: http://thelearningcurve.pearson.com/content/download/bankname/components/filename/The _Learning_Curve_2014-Final_1.pdf, [Accessed 31/10/2017].
} 
schools education classes have the average number of 35 students. The class is consider as a small community led by a teacher, with a strong focus on developing relationships between peers.

The current education system in Korea is based on Scheme 6-3-3-4. It consists of:

- Elementary School lasts 6 years (from 6 years old to 12 years old)

- Lower secondary school lasts 3 years (from 12 years old to 15 years old)

- Secondary school lasts 3 years (15 years old to 18 years old)

- Studies last 3-4 years

Korean school year begins in March. Winter holiday lasts 3 months and summer holiday last 1,5 month. The Exams (in the form of tests) of all courses lasts all day. During one day the knowledge of all courses must be successfully passed. The most important part of the exams is the half-hour test, checking the comprehension of hearing - Korean language test in the morning and later on during the same day, in the afternoon it is conducted English language test. In the whole country there is a nationwide silence. Students listen to the recorded dialogue and respond to the related questions.

In Korea the exams results are very important. Koreans are convinced that the test results not only allow them to apply to the best universities but it is also a condition of the higher social status of a young citizen. On the day of Lower Secondary School Graduation Exam (the State College Scholastic Ability Test), there is absolute silence around the school. The street traffic is stopped, the police patrol is in the streets, ensuring that no one is disturbed by the students who write the exam. The stores, banks, and even stock exchanges are opened later than usual. Sometimes it even happens that the air traffic is stopped, so that the aircraft flying over the school should go another way in order not to make too much noise ${ }^{2}$.

\section{Japan}

The school year in Japan is divided into three parts. It starts in April and ends in March. Each trimester ends with exams for that the young Japanese are preparing as hard as the Koreans. Summer vacation in Japan lasts 5 weeks, and winter and spring holidays last 2 weeks. Even during the holiday period students

\footnotetext{
${ }^{2}$ Kang, M. O. (2015). Multicultural education in South Korea. Language, ideology, and culture in Korean language arts education. New York: Routledge, pp. 34, 52-54.
} 
cannot rest. Teachers ask them to do a lot of homework. During the holiday period the students are obliged to develop their interests.

Additionally, apart the public schools in Japan, there is a parallel system of private schools called "juku", the most of the students in the afternoons attend the private tutoring lesson in order to prepare themselves better for exams. The cleaning service staff in Japanese schools does not exist. The students take care of the clearance of the halls, corridors and toilets by themselves. Students of junior classes do not have to wear the school uniforms but in lower secondary schools such a formal uniform is compulsory.

In Japan they obey the 5-level system of learning:

- kindergarten - lasts from 1 year to 3 years (from 3 years old to 6 years old)

- elementary school - education lasts 6 years (from 6 years old to12 years old)

- lower secondary school - education lasts 3 years (from 12 years old to 15 years old)

(After graduating from junior high school, the Japanese students have no obligation to study further. However, more than $95 \%$ of Japanese citizens are trying their best to get to high schools that have different requirements and levels of advanced education).

- upper secondary school - education lasts 3 years (from 15 years old to 18 years old)

- university - the education lasts 4 years / semi-high schools education lasts $2-3$ years

In Japan, they extremely pay attention to the seniority system. The teacher is the most important person in the school and during the classes the absolute discipline prevails. The school rooms are often designed as the open-spaces and sometimes there is no wall separates them from the corridor. The younger students must treat their older colleagues respectfully and overtake their school duties such as classrooms cleaning.

In the secondary schools five times a year the student need to take five tests of five different courses. The students from all schools write the same tests at the same time. The questions are set by the district authorities and are checked by the teachers who teach at the school. The same system is also observed in upper secondary schools. The number of students in the class (in 
each class is 40 people) is determined by the guidelines of the Ministry of Education ${ }^{3}$.

\section{Singapore}

The key to the success of the education system in Singapore is the quality of education and the professionalism of the teaching staff. Singapore has one of the most rigorous teachers education systems. Founded in 1991, the National Institute of Education is Singapore's is the only unit that teaches future career teachers and educates those already actively working in schools. During the first years of school work the young teachers are assigned to the supervision of the experienced tutors.

The level of education is very high in Singapore, with a high illiteracy rate among Singaporeans. The language in which the classes are conducted is English.

Children can attend the private pre-school, (from 3 years old to 6 years old), where they can learn a variety of subjects such as: Mathematics, Music and English and their official mother tongue (Mandarin, Malay or Tamil). If the parents prefer their child to learn Mandarin as the second language it is also possible. They may also choose to send their children to a church or religiousbased school.

Primary schools for pupils starts at age of 6 and lasts 6 years. To graduate from the primary school, the children must pass the final test called Primary School Leaving Examination (PSLE). The result of that exam decides whether the student is ready to leave the primary school. The result also determinates to which type of the secondary school the child can be assigned and can attend.

These are the 3 types of secondary schools in Singapore:

- Express - traditional four years of secondary education leading directly to Singapore-Cambridge O-level exam;

- Normal (Academic) - four years of education leading to the Normal-level exam ( $\mathrm{N}$-level) - with the possibility to undertake second year of the studies that leads to O-level of Express school;

- Normal (Technical) that is similar to normal (Academic) regardless of the fact that they will undertake more technical based topics like Design or Technology

3 Clark, N., (2005). Education in Japan. [ONLINE], available at: https://wenr.wes.org/2005/05/wenr-mayjune-2005-education-in-japan. [Accessed 28/10/17]. 
The students of secondary schools in Singapore are obligated to attend the course of the second mother language or they can also choose the higher mother language course. They have to attend between six and 10 courses on level " 0 " that are mandatory including English language, mother language (or higher mother language), Mathematics, one course of Science and one of Humanities elective and other optional courses like Computing or Theatre Studies, etc. The Singaporean students are forbidden to undertake the education in international schools without the permission of Ministry of Education.

Each Singaporean teacher has the right to spend 100 paid hours per year on improving their skills. Singapore authorities ensure that teachers are motivated by the right pay. The salary of a beginner teacher is at about the same level as the young engineers or accountants. The average annual salary of teachers in Singapore, after purchasing power parity, is 46,000 dollars. This is the best result among 21 best developed countries of the world. These who have the best teaching achievements, can get the extra bonuses ${ }^{4}$.

\section{Hong Kong}

Hong Kong is another Asian country, in which there is a cult of science. The achievement in the area of science is a result of hard work. The parents here are obsessed with the education of their children. If school teachers do too little homework for their children, they immediately intervene in school and report their neglect. More than $70 \%$ secondary school students in Hong Kong attend the private lessons tutoring. The most important subjects in the school are Chinese, Mathematics and English.

Primary Schools starts usually from the age of 6 and lasts till the age of 12 . They make six courses during primary school: English, Chinese, Mathematics, General Studies, Music and Psychical Education. It is possible to attend the religious school, so that it will be necessary to attend the bible/religion lessons as well.

There are also many numerous classes in the local schools - 42 students are educated in one class group on average. With so many groups, teachers often need to use the microphones during the lessons. Working in groups and activate the discussions do not happen here very often. Students and teachers pay a huge attention to the exams and the results. The high result of the exam can open the door to the best schools in the country.

\footnotetext{
${ }^{4}$ Hogan, D., (2014). Why is Singapore's school system so successful, and is it a model for the West? [ONLINE], available at: http://theconversation.com/why-is-singapores-school-system-sosuccessful-and-is-it-a-model-for-the-west-22917. [Accessed 28/10/2017].
} 
Secondary schools is divided to the junior and senior years. In junior classes they study the courses that they studied in primary school like: History, Geography and Science. In senior classes the students can choose which courses they can attend.

Further education considers the vocational education, that means that mainly the students work and study to have the practical work experience. Further studies are also possible in Hong Kong Institute of Vocational Education or at universities out of Hong Kong ${ }^{5}$.

Finland

In Finland, the school is the centre of the community and it shapes the student's identity. The Finnish student spends relatively little time in school, and the students day is full of extracurricular activities. The Finnish believe that the best place to learn is the outside of the classroom. The exception is sports activities that are not sponsored by the school, but they are paid by the city authorities.

Children attend the school for the first time at the age of 7. They do not wear uniform and they call the teachers by their names. One-third of the subjects in high school are free choice subjects. Students also choose which ones they want to take on the final secondary school exam. Children under 16 yearold do not pass any exams. The Finnish classes are not numerous. On average, between 15 and 20 young people are taught in one group.

The profession of teacher in Finland is treated with a big respect. Pedagogy in the field of study as prestigious as medicine or law in other countries. It is very difficult to apply for the studies of that course. One of ten of candidates are eligible. To start teaching at school, the teacher must have at least a master's degree. Although being teacher a very respected profession, the salaries of Finnish beginner teachers is 30.5 thousand dollars per year - it is just $13 \%$ higher than the OECD countries average salary.

Teachers in Finnish schools work 600 hours a year. The rest of the time is devoted to improving their professional skills, meetings with students and their parents. In comparison, in the United States, teachers spend more than 1100 hours a year at the table. Finnish teachers teach only during 4 lessons a day. Two hours a week is devoted to their professional development. They have a great

\footnotetext{
${ }^{5}$ Bray, M., \& Adamson, B., \& Mason, M. (2007). Comparative Education Research: Approaches and Methods, Hong Kong, pp. 40-41, 63-65.
} 
deal of freedom in teaching. They do not blindly follow the instructional scripts but adapt the teaching style and material to each student separately.

Finnish people know that if they want to succeed they have to learn languages. Apart Finnish and Swedish as mandatory course, the knowledge of English, German, French or Russian is also required in schools. No one else in the world speaks Finnish, so the citizens of this country are aware that foreign language skills are a necessity. In Finland, there is no way to compare schools in rankings. If the school is not closed yet, it means that it is good. There is no private education, tuition fees are illegal.

Finland is really impressive country in case of their education system development. They reformed the education system for 30 years. In the past, Finland was a very poor country, the wood was almost the only natural resource there. Currently, Finland's wealth is well educated citizens. Finland as a country with a small fire wood processing turned to the world's largest electronic company called "Nokia" 6 .

\section{European educational system on example of Romania and Poland}

The Romanian and Polish educational systems bring their citizens many opportunities to develop themselves. The both systems are very similar but there exist some aspects that distinguish them from each other. Thanks to the membership in European Union, the students from both countries can attend the international exchange called Erasmus Lifelong Learning Programme, so that they can study abroad or get the international practice experience. There are also various Erasmus projects thanks to that the students can practice their skills and meet people from all around the world. Below there is a characteristics of educational systems of both countries.

\section{Romania}

The educational system in Romania is uniform and centralized. About $80 \%$ of the schools implement a national educational program while the remaining $20 \%$ complete the program established by the school. Schools can be selfcontained or grouped together. They are run by local governments that receive educational subsidies from the state budget.

${ }^{6}$ Czech-Włodarczyk, C., \& Potulicka, E., \& Hildebrandt-Wypych, D. (2013). Systemy edukacji w krajach europejskich. Kraków: Oficyna Wydawnicza Impuls, pp. 73-74, 253-261. 
The first level of education is kindergarten, which is attended by $85 \%$ of children in age between 3 years old and 5 years old. Five-year-old children are under by compulsory pre-school education. Primary school lasts 4 years (from 6 years old until 10 years old), the lower secondary school (gymnasium) also lasts 4 years (from years old 10 until 14 years old).

The mandatory school attendance in Romania lasts until the $10^{\text {th }}$ class is successfully passed (15-16 years old). After $10^{\text {th }}$ class grade the student is not obligated for further education.

After graduating from lower secondary school, the pupils may continue their education in: general secondary school, the specialized secondary school (e.g. with the extension of particular courses: sports, theological, mathematical or artistic) or vocational (technical) secondary school. The students completing the type of secondary school need to pass the final exam and students of technical secondary school receive a diploma confirming their professional qualifications.

Another form of education after graduating from lower secondary school (gymnasium) which can be practiced by students is learning in the school of services and arts (vocational school), it takes 3 years and prepares for the profession (e.g. bricklayer, locksmith).

Secondary school students (17-18 years old) who completed their school may: work, continue their studies at a post-secondary school or at the university. The education on level of university can be taken in the college (lasts 2-3 years) with the possibility of receiving diplomă de absolvir or the education can be continued in the university on level bachelor and after 3-4 years of studies, the student can get diplomă de licență or diplomă de inginer. The master's level studies last 1-2 years and the students graduate with diplomă de studii aprofundate. The students can studies at public universities for free or they can attend the private universities that are paid. Students who decide to attend the paid studies, mainly work and study at the same time as the classes take place during the weekend.

Most of Romanian students speak fluent English. Romanian students very eagerly attend various international exchange programmes. They can participate the studies in the foreign countries at the partnership universities or they go for Erasmus. There are plenty types of scholarships they can apply for.

Teachers at Romanian schools who want to gain further degrees of career advancement need to take the internship in a facility in collaboration with 
university researchers and inspectors and mainly the internship is done in a form of conducting research during the teacher's internship ${ }^{7}$.

Poland

The educational system of Poland is very similar to Romanian one and currently is being reformatted.

After the finalizing the process of reformation of the education system of Poland the targeted school structure will include:

- 8-year elementary school

- 4-year general secondary school

- 5-year technical school

- 3-year first-cycle vocational school

- 2-year second-cycle vocational school

The new system brought the closure of two types of school: gymnasium school (for pupils in age 13-15 years old) and the main vocational school. The main vocational school is replaced by first-cycle vocational school and secondcycle vocational school.

Children in the age of 3-5 years old can attend the kindergarten but it is not mandatory. After the educational reform, primary school starts for children that are in age of 6 and the first year is call " 0 class" so that the children during the classes do not have so much to study. The time is spent on finding out the letters, drawing, counting, playing in the groups etc. After that first year children start 8-year education in elementary school. First three years of education are spent on counting, reading, musical and artistic education without the normal weekly lessons plan. There are no marks and the all lessons are conducted by one teacher.

The next 5 years of the education in elementary school in Poland bases on the weekly courses plan. The pupils have to attend the courses of: Polish language, Mathematics, History, Science, Music, Art, Psychical Education and Foreign Language course. By the end of each school year, students get the final grades from the teachers of all the courses and they are showed on the school diploma. If parents want the students can attend the religious classes or ethics. In the past, the primary school was finalised by the exam, currently after the

7 Heller, A., (2015), Warunki życia i pracy w krajach Europejskiego Obszaru Gospodarczego Rumunia. [ONLINE], available at:

https://eures.praca.gov.pl/zal/warunki_zycia/rumunia/Rumunia3.pdf. [Accessed 9/11/2017]. 
reform of the polish education system, there is no exam at primary school. After turning the age of 18 , the students are not obligated for further education.

After graduating from primary school, the children can choose the type of the school they want to attend. They can go to: secondary school (there are the classes with the extension of some courses like: Biology, Literature, Foreign Languages, Sports, etc.), technical school and the vocational school that is divided into two streams after the new reform. In secondary school, students pay a great attention to learn foreign language. The knowledge of English, German or French is very common among Polish teenagers.

Students graduating from secondary school have to take the final exam and the result decides about their future university career. Technical school is also finalised with the profession exam after that, the student get the certificate confirming their professional skills. In vocational school there is no final exam the students receive the diploma confirming they attended the school.

Mainly, students graduating from secondary school, decide to continue the education at the university. After 3-4 years of studies, they graduate with the degree of bachelor or engineer and after another 2 years of education, the education is finalised with the degree of master. Many students attend the private universities, so they can study and work at the same time, as the classes are during the weekend.

Participation in the international exchange programmes like Erasmus is very common among polish students. They decide to try their skills abroad as they can bring them better start in their professional career.

The functioning of the education system in Poland is based on the work done by teachers and other employees employed in educational institutions. Teachers are obliged to improve their qualifications under the teacher promotion system ${ }^{8}$.

\section{Conclusions}

The importance of the implementation of the appropriate educational system in the countries is vital for better future of their citizens. The main

\footnotetext{
${ }^{8}$ Ministery of National Education, (Sept 2016), Reforma edukacji - prezentacja projektów ustaw. [ONLINE], available at: https://men.gov.pl/ministerstwo/informacje/reforma-edukacjiprezentacja-projektow-ustaw.html. [Accessed 10/11/2017].
} 
condition of reforming the internal education system of the country is defendant from the money transfers sponsored by the authorities. It is also very important to educate the teachers very well and give them the possibility for further development of their skills.

Asian countries and Finland pay a great attention to ensure the students the very good education level. Investing in the educational system development brought the Asian countries and Finland the title of the leaders of the innovation in area of IT and electronics.

The contrast between the Asian and European educational system is huge. Asian countries can afford to spend much more money of state budget for internal educational system but the system is more strict towards the students. European countries seem to spend less money of educational system than Asian countries do but it does not mean that the education is on worse level. Most of the students are very ambitious and decide to continue the education at universities. In European countries students pay a great attention to learn foreign language that opens them the door to try their best abroad.

Basing on the example of Poland and Romania, it might be seen the very common kind of the educational system that is spread among many European countries. Both systems are aimed to provide their student very good and advanced education level. In these countries the attendance in the Erasmus programme is very common and it gives an opportunity to get and improve the foreign language skills.

\section{References}

[1] Bray, M., \& Adamson, B., \& Mason, M. (2007). Comparative Education Research: Approaches and Methods, Hong Kong.

[2] Clark, N., (2005). Education in Japan. [ONLINE], available at: https://wenr.wes.org/2005/05/wenr-mayjune-2005-education-in-japan.

[Accessed 28/10/17].

[3] Czech-Włodarczyk, C., \& Potulicka, E., \& Hildebrandt-Wypych, D. (2013). Systemy edukacji w krajach europejskich. Kraków: Oficyna Wydawnicza Impuls.

[4] Fallon, J., \& Barber, M., \& the others. (2014). The Learning Curve 2014. [ONLINE], available at: http://thelearningcurve.pearson.com/content/download/bankname/compo nents/filename/The_Learning_Curve_2014-Final_1.pdf [Accessed 31/10/2017].

[5] Hogan, D., (2014). Why is Singapore's school system so successful, and is it a model for the West? [ONLINE], available at: http://theconversation.com/why-is-singapores-schoolsystem-so-successful-and-is-it-a-model-for-the-west- 22917.

[Accessed 28/10/2017]. 
[6] Heller, A., (2015), Warunki życia i pracy w krajach Europejskiego Obszaru Gospodarczego - Rumunia. [ONLINE], available at: https://eures.praca.gov.pl /zal/warunki_zycia/rumunia/Rumunia3.pdf. [Accessed 9/11/2017].

[7] Kang, M. O. (2015). Multicultural education in South Korea. Language, ideology, and culture in Korean language arts education. New York: Routledge.

[8] Ministery of National Education, (Sept 2016), Reforma edukacji - prezentacja projektów ustaw. [ONLINE], available at: https://men.gov.pl/ministerstwo/inf ormacje/reforma-edukacjiprezentacja-projektow-ustaw.html. [Accessed 10/11/2017].

[9] Pe Symaco, L., (2013). Education in South-East Asia. New York: Bloomsbury Publishing. 